\title{
Euroregion Karpacki - innowacyjna forma integracji społeczności lokalnych i regionalnych w Europie Środkowo-Wschodniej
}

\section{Wstęp}

Idea współpracy zarówno lokalnych, jak i regionalnych społeczności, wykraczającej poza granice państwowe ma już na obszarze Europy wieloletnią historię i stała się niezbędnym czynnikiem pobudzającym rozwój terenów objętych jej zasięgiem. Idea ta zrodziła się w latach pięćdziesiątych XX wieku w Europie Zachodniej. Jej prekursorami były obszary sąsiadujących ze sobą Niemiec i Francji, Niemiec i Holandii oraz państw półwyspu skandynawskiego. Nieco później, w latach osiemdziesiątych rozpoczęto współpracę transgraniczną w niektórych krajach zachodnioeuropejskich, takich jak: Grecja, Hiszpania czy Portugalia, a także w krajach Europy Środkowo-Wschodniej, w tym Polski (Gwizdała, 2015).

Zmniejszanie nierówności i wykluczenia społecznego w Europie są kluczowymi wyzwaniami dla przyszłości Europy. Jednocześnie, istnieje ogromny potencjał dla Europy dzięki możliwościom jakie dają, na przykład, nowe formy innowacji i zaangażowania obywateli. $\mathrm{Z}$ tego powodu wspieranie społeczeństw integracyjnych, innowacyjnych i refleksyjnych jest warunkiem trwałej integracji europejskiej. Procesy innowacyjne można zatem określić jako ciągłe dążenie do doskonalenia produktów, struktur organizacyjnych, procesów produkcyjnych i biznesowych oraz zasobów ludzkich (Goliński, 1999, s. 145). Sama innowacja powinna być natomiast rozumiana jako zmiana; coś, co jest traktowane jako nowe (Kasperkiewicz, Mikosik, 1993, s. 53). W związku z zasadami pomocniczości i decentralizacji istotną część zadań publicznych wykonuje samorząd terytorialny. Zagadnienie rozwoju innowacyjności w zadaniach samorządu terytorialnego powinno być analizowane w związku z rozwojem lokalnym i regionalnym, a zwłaszcza może wiązać się ze współpracą transgraniczną, w ramach euroregionów.

Najbardziej zinstytucjonalizowaną formą współpracy transgranicznej jest współpraca $\mathrm{w}$ ramach euroregionów, która powstała w wyniku porozumienia pomiędzy władzami lokalnymi i regionalnymi. W wyniku funkcjonowania euroregionów w praktyce zaobserwowano, że stanowią one jedyną skuteczną formę przełamywania barier zarówno społecznych, jak i gospodarczych czy też politycznych. Także Unia Europejska czerpie korzyści z ich funkcjonowania, uważając je za istotny element procesu politycznej integracji, dlatego też wspiera finansowo ich działalność. Dzięki wsparciu Unii Europejskiej możliwa stała się realizacja 
na obszarach objętych współpracą euroregionalną wielu projektów o charakterze transgranicznym.

Polska odegrała olbrzymią rolę w inicjowaniu współpracy w ramach euroregionów. Na obszarze Polski znaczący rozwój euroregionów nastąpił na początku lat dziewięćdziesiątych XX w. Początkowo największa intensywność rozwoju współpracy euroregionalnej miała miejsce na granicach zachodnich Polski. Tam też powstał pierwszy polski euroregion - Euroregion Neisse-Nisa-Nysa (1991 r.).

Z kolei drugim euroregionem utworzonym w 1993 r. na granicach Polski był Euroregion Karpacki, był to pierwszy euroregion utworzony w Europie Środkowo-Wschodniej. W Polsce jest to jeden $\mathrm{z}$ dwóch euroregionów (obok Euroregionu Bałtyk), który obejmuje swym zasięgiem aż pięć państw - Polskę, Rumunię, Słowację, Ukrainę oraz Węgry. Utworzenie oraz funkcjonowanie tego Euroregionu stanowić miało dużą szansę rozwoju dla peryferyjnych obszarów, będących w zasięgu jego działań (na obszarze Polski dla całego województwa podkarpackiego).

Celem tego artykułu jest podjęcie próby wyjaśnienia wpływu społeczności lokalnych i regionalnych na rozwój lokalny i regionalny oraz przedstawienie osiągnięć Euroregionu Karpackiego, na przykładzie działalności Stowarzyszenia Euroregion Karpacki Polska oraz ukazanie jego roli w procesie integracji europejskiej.

$\mathrm{Na}$ potrzeby niniejszego artykułu dokonano analizy internetowej bazy danych zawierających informacje na temat przedsięwzięć realizowanych ze środków europejskich. Na potrzeby niniejszego tekstu autorka sięgnęła również do stosownych raportów i sprawozdań oraz literatury przedmiotu, podejmującej szeroko rozumianą problematykę obszarów euroregionalnych. Punktem odniesienia prezentowanego artykułu jest dynamicznie rozwijająca się koncepcja podmiotowości społeczności lokalnych. Pojęcie podmiotowości odnosi się do wielu wymiarów rzeczywistości społecznej i ma charakter interdyscyplinarny. Szczególnego znaczenia nabiera w przestrzeni lokalnej, gdzie dostrzec można szczególne rodzaje powiązań społecznych oparte na partnerstwie i współpracy.

\section{Wspólpraca transgraniczna i euroregionalna w Europie}

Konieczność rozpoczęcia współpracy transgranicznej narodziła się w latach osiemdziesiątych dwudziestego wieku. Ludność właśnie wtedy zaczęła odczuwać silną potrzebę nawiązywania bliższych kontaktów z innymi ludźmi zamieszkującymi sąsiadujące tereny, co wynikało głównie z chęci stworzenia poczucia bezpieczeństwa, wzajemnego zaufania i pewnej stabilizacji.

Pojęcie współpracy transgranicznej zostało zdefiniowane w Europejskiej Konwencji Ramowej o Współpracy Transgranicznej między Wspólnotami i Władzami Terytorialnymi, sporządzonej w Madrycie w maju 1980 r. (Konwencja Madrycka). Zgodnie z jej drugim artykułem: „za współpracę transgraniczną uważa się każde wspólnie podjęte działanie mające na celu umocnienie i dalszy rozwój sąsiedzkich kontaktów między wspólnotami i władzami terytorialnymi dwóch lub większej liczby umawiających się stron, jak również zawarcie porozumień i przyjęcie uzgodnień koniecznych do realizacji takich zamierzeń. Współpraca transgraniczna ograniczona 
jest ramami właściwości wspólnot i władz terytorialnych, w sposób określony przez prawo wewnętrzne".

Jedną z form współpracy transgranicznej na szczeblu lokalnym jest współpraca euroregionalna. Współpraca transgraniczna jest więc pojęciem szerszym niż współpraca euroregionalna. Podstawą różniącą obie te formy współpracy jest fakt, że ,,współpraca transgraniczna często sprowadza się do jednego konkretnego problemu, a euroregion tworzy się z myślą o długim horyzoncie czasu oraz o różnych zagadnieniach, którymi ma się zajmować” (Greta, 2003, s. 73). Współpraca euroregionalna wyróżnia się ponadto od współpracy transgranicznej wyższym stopniem instytucjonalizacji struktur współpracy transgranicznej (jak na przykład powoływanie rad euroregionu, sekretariatów, grup roboczych itp.), licznymi powiązaniami z wyspecjalizowanymi krajowymi i międzynarodowymi organami koordynacji współpracy transgranicznej oraz specyficznym charakterem powoływania euroregionu przy możliwości pierwszeństwa zarówno inicjatyw oddolnych (lokalnych), regionalnych, jak i rządowych (Borys, Panasewicz, 1997, s. 9).

Przybliżając problematykę dotyczącą współpracy transgranicznej, należy zwrócić także uwagę na samo pojęcie regionu transgranicznego. Jest to region zlokalizowany po obu stronach granicy. Tego typu regiony wykazują pewne cechy wspólne, na przykład w handlu i przemyśle oraz uzupełniają się wzajemnie. Najczęściej ludność zamieszkująca te regiony jest wielojęzyczna. W Europie tego typu regiony można klasyfikować według pewnych kryteriów. Za najważniejsze z nich uznaje się: stopień jednorodności regionu, eliminację lub niską formalizację granicy, stopień rozwoju regionu oraz jego status, położenie regionu wzdłuż granic wyznaczających obszar Unii Europejskiej, istnienie współpracy ponadgranicznej oraz stopień instytucjonalizacji struktur takiej współpracy (Dobrowolski, Łata, 2001, s. 17-18). W związku z istnieniem regionów transgranicznych społeczeństwa oczekują przede wszystkim zlikwidowania różnic przejawiających się m.in. w: różnych strukturach i kompetencjach administracji; różnych przepisach podatkowych i socjalnych; różnych przepisach o planowaniu i zagospodarowaniu przestrzennym; różnych przepisach w dziedzinie ochrony środowiska i gospodarki odpadami; parytetach walutowych; różnych systemach komunikacyjnych, które nie są nastawione na wymagania transgranicznego rynku wewnętrznego; w niespójnych rynkach pracy, strukturach płac i systemach socjalnych na granicach zewnętrznych, grożące powstawaniem konfliktów i społecznych niepokojów; utracie poczucia bezpieczeństwa w wyniku otwarcia granic; trudnościach w zakresie transgranicznego kształcenia zawodowego, co jest istotną barierą w funkcjonowaniu Europejskiego Rynku Wewnętrznego oraz transgranicznego rynku pracy, a także w istniejących po obu stronach uprzedzeniach, stereotypach, braku empatii i zrozumienia dla inności sąsiada ${ }^{2}$.

Przyczyny podejmowania współpracy transgranicznej w Europie to przede wszystkim: przekształcenie granicy z elementu dzielącego w miejsce pełniące rolę spotkań sąsiadów; przezwyciężenie wzajemnych uprzedzeń i urazów pomiędzy mieszkańcami

${ }^{1}$ Europejska Konwencja Ramowa o wspótpracy transgranicznej między wspólnotami $i$ władzami terytorialnymi, Madryt, 21.05.1980 r., Dz. U. 1993, Nr 61, poz. 287, http://msp.money.pl/ akty_prawne/dzienniki_ustaw/, 7.05.2019.

${ }_{2}^{2}$ Europejska Kartä Regionów Granicznych i Transgranicznych, https://docplayer.pl/7365320Europejska-karta-regionow-granicznych-i-transgranicznych-nowelizacja.html, 7.05.2019. 
obszarów nadgranicznych wynikających z dziedzictwa historycznego; rozwój demokracji i administracji na szczeblu regionalnym i lokalnym; przezwyciężenie peryferyjnego położenia i izolacji w odniesieniu krajowym; wzrost gospodarczy i podniesienie poziomu życia; szybkie zbliżenie oraz zintegrowanie z Unią Europejską̧3.

Z kolei, idea tworzenia euroregionów narodziła się w Europie Zachodniej zaraz po zakończeniu II wojny światowej, w celu zbliżenia skłóconych ze sobą społeczności z powodów narodowościowych, bądź też politycznych. To właśnie euroregiony w Unii Europejskiej odegrały dużą rolę w nawiązaniu i zacieśnianiu kontaktów pomiędzy krajami członkowskimi Unii, jak i w integracji z krajami do niej kandydującymi.

Współpraca euroregionalna najczęściej obejmuje takie dziedziny, jak: ochrona środowiska, rozwój infrastruktury technicznej, planowanie przestrzenne, turystyka, kultura, ochrona przed katastrofami oraz restrukturyzacja przemysłu i rolnictwa (Dobrowolski, Łata, 2001, s. 17-18). Charakteryzuje się ona przede wszystkim „najwyższym stopniem instytucjonalizacji i struktur współdziałania ponadgranicznego. Jest ona głównie realizowana przez władze lokalne, bądź władze regionalne. Może ona dotyczyć konkretnych, wspólnych projektów oraz inwestycji, które wymagają koordynacji graniczących ze sobą społeczności lokalnych. To właśnie tego typu euroregiony aktualnie powstają najczęściej.

Powstawanie euroregionów jest głównie uwarunkowane interesami politycznymi, bądź też ekonomicznymi. Mają one za zadanie przyczyniać się dostarczania korzyści wynikających ze wspólnego działania, pomimo występowania granic oraz zdobywania pewnych doświadczeń ułatwiających przystąpienie do szerszej integracji europejskiej.

Współpraca euroregionalna może obejmować płaszczyznę tradycyjną, związaną z tranzytem, przejściami granicznymi i kontrolą graniczną, ale może także dotyczyć konkretnych przedsięwzięć inwestycyjnych, wymagających ścisłej koordynacji działań graniczących ze sobą społeczności lokalnych (takie euroregiony powstają obecnie najczęściej), bądź może przyjmować wyższą formę, co oznacza, że podejmuje się prowadzenia wspólnej polityki społecznej i ekonomicznej, skupiającej się na rynku pracy, ochronie zdrowia, problemach rozwoju lokalnego przemysłu i usług oraz rozwoju miast przygranicznych (ten etap osiągnęła na przykład współpraca robocza Pirenejów) (Stasiak, 1999, s. 119).

Istniejące już euroregiony wypracowały pomiędzy sobą wiele zasad współdziałania. Najważniejsze z tych zasad to: zasada subsydiarności (pomocniczości), zasada partnerstwa, równoprawności i równorzędności państw tworzących dany euroregion, zasada solidarności obszarów transgranicznych czy zasada istnienia koncepcji bądź strategii rozwoju transgranicznego (Dobrowolski, Łata, 2001). Równie ważne zasady, które zostały wypracowane w praktyce funkcjonowania euroregionów, to przede wszystkim zasada: dobrego sąsiedztwa, zachowania tożsamości, dobrowolności, dążenia do symetrii i parytetów, pragmatyzmu, kierowania się przyjaźnią i zaufaniem, rotacji oraz zasada consensusu (Borys, 1999, s. 90-91).

Współpraca transgraniczna stanowi pewien rodzaj współpracy międzynarodowej. Charakteryzuje ją przede wszystkim wzajemna bliskość w relacjach między obszarami przygranicznymi oraz występujący między nimi poziomami współpracy o charakterze lokalnym lub regionalnym. Jest to pewnego rodzaju proces mający na celu dążenie do

${ }^{3}$ Praktyczny podręcznik wspótpracy transgranicznej, http://www.aebr.net/publikationen/pdfs/ lace_guide.pl.pdf, 7.05.2009, s. 1-8. 
niwelowania problemów pomiędzy obszarami przygranicznymi, pomimo występowania barier między tymi obszarami, jakie stanowią właśnie granice państwowe. Można, więc powiedzieć, że współpraca transgraniczna stanowi swego rodzaju ,pomost” pomiędzy państwami w procesie integracji, gdyż dzięki takiej współpracy dochodzi do stopniowego przeobrażenia się pojęcia granica, która nie jest już rozumiana, jako linia na mapie, kończąca teren jednego obszaru i zarazem rozpoczynająca inny, odmienny obszar terytorialny. Dochodzi wręcz do zacierania się granic pomiędzy państwami, nadania im znaczenia czysto administracyjnego.

Współpraca transgraniczna rozwijała się stopniowo, zaczynając od całkowitego braku stosunków, poprzez wymianę informacji, konsultacje, współpracę i harmonizację, aż do mementu pełnej integracji.

Do tej pory współpracę w ramach euroregionów na terenie całej Europy ocenia się korzystnie, gdyż sprzyja ona nawiązywaniu częstych kontaktów, przezwyciężaniu stereotypów oraz wymaga podejmowania ciągłej współpracy pomiędzy społecznościami lokalnymi, samorządami, jak i władzami terytorialnymi. Współpraca pomiędzy sąsiadującymi ze sobą obszarami pozwala także: „skutecznie przełamywać wcześniej istniejące obopólne uprzedzenia i zastępować je wzajemnym zaufaniem oraz dobrymi stosunkami sąsiedzkimi, sprzyjając tolerowaniu odmiennych systemów wartości, a niekiedy prowadząc do akceptacji wielokulturowości. Pojawia się duża ruchliwość społeczna, coraz silniejsza wzajemna znajomość i zrozumienie dla odmienności, przenikalne granice międzygrupowe, duża liczba heterogenicznych instytucji” (Malendowski, Szczepaniak, 2000, s. 51). Ta pozytywna opinia dotycząca funkcjonowania euroregionów pozwala na ciągły rozwój współpracy transgranicznej na obszarze całej Europy.

\section{Geneza współpracy euroregionalnej w Euroregionie Karpackim}

Powołanie Międzyregionalnego Związku Euroregion Karpacki, miało miejsce w Debreczynie na Węgrzech, dnia 14 lutego 1993 r. Dokumenty założycielskie zostały podpisane przez przedstawicieli władz lokalnych i regionalnych Polski, Ukrainy, Słowacji i Węgier w obecności Catherine Lalumiere, ówczesnego Sekretarza Generalnego Rady Europy. Ministrowie spraw zagranicznych tych państw także poparli ideę utworzenia Euroregionu Karpackiego, poprzez podpisanie Deklaracji o Współpracy Społeczności Zamieszkującej Obszar Euroregionu Karpackiego. W kwietniu 1997 r. do Euroregionu Karpackiego przystąpiła także Rumunia, której wniosek o przyjęcie jej jako Członka Zwyczajnego został rozpatrzony pozytywnie na posiedzeniu Rady Związku w dniach 29-30 kwietnia 1997 r.

Znaczącym krokiem ku utworzeniu tego Euroregionu było seminarium zorganizowane w 1992 r.: „Możliwości i perspektywy współpracy sąsiadujących regionów Polski, Czechosłowacji, Węgier i Ukrainy”, które odbyło się w Jaśle. Podpisano wtedy deklarację, powołującą Radę Współpracy Międzyregionalnej Przykarpacia.

Podstawę prawną dla funkcjonowania Euroregionu Karpackiego stanowią dwa dokumenty: Statut oraz Porozumienie. W preambule Statutu Związku Międzyregionalnego Euroregion Karpacki jest on zdefiniowany jako ,organ doradczy i koordynujący, mający na celu rozwijanie współpracy transgranicznej między regionami przygranicz- 
nymi - Członkami Związku, zgodnie z Europejską Konwencją Ramową o Współpracy Transgranicznej między Wspólnotami i Władzami Terytorialnymi, oraz opartym na zasadach subsydiarności, partnerstwa i reprezentacji” (Statut Zwiazku).

Euroregion Karpacki jest jednym z najstarszych i największych euroregionów na obszarze Polski. Istnieje od 1993 r. i swym zasięgiem obejmuje po stronie polskiej gminy z województwa podkarpackiego, z powiatów: krośnieńskiego, rzeszowskiego i podkarpackiego o łącznej powierzchni $18686 \mathrm{~km}^{2}$; po stronie ukraińskiej obejmuje 4 obwody - Czerniowiecki, Iwanofrankowski, Lwowski i Zakarpacki, o łącznej powierzchni $56600 \mathrm{~km}^{2}$, słowacka część Euroregionu ma obszar $10459 \mathrm{~km}^{2}$ i obejmuje dwa kraje - Preszowski i Koszycki, strona węgierska ma obszar $28639 \mathrm{~km}^{2}$ i obejmuje 5 okręgów - Borsod-Abauj-Zemplen (Miskolc), Hajdú-Bihar (Debreczyn), Heves (Eger), Jász-Nagykun-Szolnok oraz okręg Szabolcs-Szatmár-Bereg (Nyíregyháza), natomiast strona rumuńska zajmuje powierzchnię $27104 \mathrm{~km}^{2}$ i obejmuje okręgi - Bihor, Botoşani, Harghita, Maramureş, Sălaj, Satu Mare i okręg Suceava (Małecka, 2007, s. 138-139).

Największą powierzchnię Euroregionu Karpackiego zajmuje część ukraińska, bo około 36,6\%, część rumuńska zajmuje powierzchnię około 23,1\%, część węgierska około $18,5 \%$, część polska zajmuje około $11,6 \%$ powierzchni, natomiast najmniejszą powierzchnię stanowi część słowacka, bowiem zajmuje około 10,2\% powierzchni Euroregionu (Ludność w Euroregionie Karpackim).

Terytorium Euroregionu Karpackiego obejmuje słabo rozwiniętą część każdego z krajów tworzących ten Euroregion. Są to obszary peryferyjne, słabo rozwinięte pod względem gospodarczym oraz z wysoką stopą bezrobocia i ubóstwa. Największymi miastami Euroregionu Karpackiego są Debreczyn i Miskolc na Węgrzech, Satu Mare i Baia Mare w Rumunii, Koszyce i Preszów na Słowacji, Czerniewice, IwanowoFrankfurt, Lwów i Użgorod na Ukrainie oraz Krosno i Przemyśl w Polsce (Greta, 2003, s. 144).

Euroregion Karpacki jest obszarem, na którym dochodzi do zetknięcia się wielu kultur oraz mniejszości etnicznych. Na Ukrainie występuje liczna mniejszość polska, a w Rumunii i na Słowacji mniejszość węgierska, a także we wszystkich częściach Euroregionu zamieszkują Romowie, a w niektórych również takie grupy etniczne jak - Łemkowie, Bojkowie, Huculi, Pogórzanie, Sasi i inni. Terytorium Euroregionu Karpackiego stanowi zatem mieszkankę kulturową, ale także co za tym idzie mieszankę religijną. Łączą się na nim trzy różne obrządki chrześcijańskie: rzymskokatolicki, greckokatolicki i prawosławny, a także w mniejszym stopniu występują kalwiniści, wyznawcy religii mojżeszowej, muzułmanie, protestanci i inni, co wywiera ogromny wpływ na proces euroregionalizacji.

We wschodniej części tego Euroregionu występuje klimat kontynentalny, natomiast pozostały obszar ma charakter przejściowy pomiędzy klimatem atlantyckim a kontynentalnym. Jest to związane z ukształtowaniem tego terenu. Większą część Euroregionu stanowią obszary górzyste, znajdujące się w obrębie łańcucha Karpat i jego pobliżu. W skład polskiej części Euroregionu Karpackiego wchodzi Kotlina Sandomierska, Zewnętrzne Karpaty Zachodnie (Beskid Niski oraz Pogórze Ciężkowickie, Strzyżowskie, Dynowskie i Przemyskie) oraz Zewnętrzne Karpaty Wschodnie (Góry Sanocko-Turczańskie i Bieszczady). Największy udział pod względem liczby ludności 
w Euroregionie Karpackim mają mieszkańcy Ukrainy - 40,1\%, natomiast najmniejszy mieszkańcy Słowacji - 10,3\% (Wahl, 2003, s. 118).

W Euroregionie Karpackim przeważają miasta do 50 tys. mieszkańców. W roku 2005 stanowiły one 92,6\% ogólnej liczby miast, natomiast zamieszkiwało w nich 48,4\% ogółu ludności miejskiej. W części polskiej Euroregionu występuje 5 miast liczących powyżej 50 tys. mieszkańców: Rzeszów, Przemyśl, Stalowa Wola, Mielec i Tarnobrzeg. W części rumuńskiej występuje 6 takich miast: Oradea, Baia Mare, Botosani, Satu Mare, Suceava i Zalau. Na Słowacji są 3 tego typu miasta: Koszyce, Preszów i Poprad. W części ukraińskiej znajduje się 10 takich miast: Lwów, Czerniowce, Iwano-Frankowsk, Użgorod, Drohobycz, Czerwonogród, Mukaczewo, Kałusz, Stryj i Kołomyja. Natomiast w części węgierskiej jest 5 tego typu miast: Debreczyn, Miszkolc, Nyiregyhaza, Szolnok i Eger (Ludność w Euroregionie Karpackim).

Dnia 6 grudnia 2002 r. w Koszycach na Słowacji została przeprowadzona reforma Związku Międzyregionalnego Euroregion Karpacki, w wyniku której doszło do ustanowienia następującej struktury organizacyjnej Związku, składającej się z takich organów jak: Rada Euroregionu, Przewodniczący Rady Euroregionu, Sekretariat Międzynarodowy oraz Biura Krajowe Euroregionu. Według Statutu organy te mają spełniać przede wszystkim funkcje doradcze, konsultacyjne, koordynacyjne i reprezentacyjne, a także mają służyć rozwijaniu współpracy międzyregionalnej pomiędzy Członkami Związku. Decyzje przez nie podejmowane mają jednak jedynie charakter propozycji wobec Członków Związku (Statut Związku).

\section{Działalność Stowarzyszenia Euroregion Karpacki Polska a integracja europejska}

Stowarzyszenie Euroregion Karpacki Polska powołano dnia 4 lipca 2000 r. z inicjatywy przedstawicieli środowisk społecznych, naukowych i samorządowych województwa podkarpackiego. Stowarzyszenie powstało także dzięki pozytywnej opinii Komisji do spraw Współpracy Międzynarodowej. Działa ono w oparciu o ustawę z dnia 7 kwietnia 1989 r. „Prawo o Stowarzyszeniach” (Dz. U. 2001, Nr 79, poz. 855 z późn. zm.) oraz na podstawie Statutu Stowarzyszenia Euroregion Karpacki Polska. Stowarzyszenie ma swoją siedzibę w Rzeszowie. Zasięgiem jego działań jest obszar polskiej części Euroregionu Karpackiego, a także części ukraińskiej, słowackiej, rumuńskiej i węgierskiej oraz obszar Unii Europejskiej. Utworzenie tego Stowarzyszenia przyczyniło się głównie do uregulowania ram formalno-prawnych funkcjonowania polskiej części Euroregionu Karpackiego. Stowarzyszenia tego typu, oprócz Polski, funkcjonują także na Słowacji (Stowarzyszenie Region Karpacki Słowacja) oraz na Ukrainie (Zrzeszenie Samorządów Euroregion Karpacki Ukraina). Natomiast jeśli chodzi o dwa pozostałe kraje tworzące Euroregion Karpacki, czyli Węgry i Rumunię, to nie posiadają one osobowości prawnej, ani struktur organizacyjnych.

W rozdziale II Statutu Stowarzyszenia Euroregion Karpacki Polska zostały wyszczególnione jego priorytetowe cele. Celem Stowarzyszenia jest m.in.: tworzenie rzeczywistych struktur współpracy transgranicznej i międzyregionalnej na terytorium Związku Międzyregionalnego Euroregion Karpacki - regionach przygranicznych 
państw leżących na obszarze Karpat, w oparciu o prawo krajowe i europejskie, na zasadach partnerstwa poziomego i pionowego, subsydiarności i demokratycznej reprezentacji podmiotów sektora: publicznego, prywatnego i pozarządowego; koordynacja wykorzystania pomocy Unii Europejskiej przeznaczonej na współpracę transgraniczną i międzyregionalną w zakresie planowania, programowania, zarządzania, wdrażania i monitorowania działań: projektów, programów, strategii transgranicznych i międzyregionalnych na terytorium Związku Międzyregionalnego Euroregion Karpacki - regionów przygranicznych państw leżących na obszarze Karpat; upowszechnianie wiedzy o historii, tradycjach i kulturze polskiej; pogłębianie współpracy i rozwój dobrych stosunków pomiędzy państwami należącymi do Związku Międzyregionalnego Euroregion Karpacki; promowanie wspólnych działań z zakresu ochrony środowiska i utrzymania zasobów przyrody; rozwój turystyki i agroturystyki; harmonijny rozwój gospodarczy regionu; upowszechnianie wiedzy o Euroregionie Karpackim; upowszechnianie wiedzy o gminach i powiatach, w tym szczególnie wchodzących w skład strony polskiej Euroregionu Karpackiego; upowszechnianie wiedzy o Unii Europejskiej i podejmowanych przez nią działaniach; ochrona zdrowia i podejmowanie działań profilaktycznych w tym zakresie; wymiana kulturalna i naukowa; wymiana doświadczeń z zakresu opieki socjalnej; rozwiązywanie problemów rolnictwa i środowisk wiejskich; wymiana doświadczeń z zakresu zarządzania administracją i podmiotami gospodarczymi; wymiana doświadczeń związanych z działalnością samorządów lokalnych oraz wymiana doświadczeń z zakresu rozwiązywania problemów szkolnictwa (Statut Stowarzyszenia).

Działania mające służyć realizacji tych celów to: opracowanie i wdrażanie Euroregionalnego Systemu Współpracy; podpisywanie i realizacja międzynarodowych porozumień o współpracy; reprezentowanie interesów mieszkańców z terenu województwa podkarpackiego w strukturach Związku Międzyregionalnego Euroregion Karpacki oraz Unii Europejskiej; utworzenie Międzynarodowego Centrum Współpracy Transgranicznej i Międzyregionalnej; tworzenie Lokalnych Centrów Współpracy Euroregionalnej oraz Punktów Informacyjnych Stowarzyszenia; tworzenie szkół, szkół wyższych, świetlic środowiskowych, instytutów, ośrodków doradztwa, ośrodków szkoleniowo-edukacyjnych, ośrodków rekreacyjno-wypoczynkowych, domów stowarzyszenia; utworzenie w ramach struktury Stowarzyszenia Sekretariatu Technicznego dla zarządzania programami współpracy przygranicznej; zarządzanie i wdrażanie programów współpracy przygranicznej; podjęcie działań zmierzających do koordynacji i ujednolicenia zasad funkcjonowania programów współpracy przygranicznej takich jak PHARE, TACIS, INTERREG; przygotowywanie projektów, programów i strategii w ramach programów współpracy przygranicznej w tym w ramach Inicjatywy Wspólnotowej INTERREG; udział w ciałach powołanych do wdrażania programów współpracy przygranicznej i inicjatyw wspólnotowych, takich jak: zespoły programujące, komisje oceniające, komitety sterujące, komitety monitorujące; udział w przygotowaniu Wspólnych Dokumentów Programowych oraz Uzupełnień Programów w ramach programów współpracy przygranicznej, programów rozwoju regionalnego oraz Inicjatywy Wspólnotowej INTERREG; organizacja Konwentu Samorządowego Strony Polskiej Euroregionu Karpackiego; współpraca ze szkołami i uczelniami w ramach sieci szkolnych i uczelnianych klubów Euroregionu Karpackiego; współdziałanie z władza- 
mi, instytucjami oraz innymi organizacjami podzielającymi cele Stowarzyszenia; promowanie szeroko pojętej wymiany kulturalnej, turystycznej, naukowej, gospodarczej; organizowanie seminariów, warsztatów, sympozjów, szkoleń; organizowanie spotkań mieszkańców; wspieranie lokalnych inicjatyw w zakresie przedsiębiorczości, rozwoju turystyki, wymiany kulturalnej i naukowej; występowanie z wnioskami i postulatami do władz lokalnych; współpraca z pokrewnymi stowarzyszeniami krajowymi i zagranicznymi; działalność informacyjna w mediach publicznych krajowych i zagranicznych, a także własne inicjatywy medialne (Statut Stowarzyszenia).

Bardzo ważnym narzędziem polityki Stowarzyszenia Euroregion Karpacki Polska, opracowanym przez Biuro Polskie Euroregionu Karpackiego jest Euroregionalny System Współpracy (ESW), który „stanowi instrument realizacji misji Związku Międzyregionalnego Euroregion Karpacki oraz instrument wsparcia rozwoju regionalnego, narzędzie wsparcia polityki regionalnej w zakresie współpracy transgranicznej i międzynarodowej. Cel budowy Systemu jest zatem ściśle podporządkowany celom Związku, wobec których pełni on rolę wykonawczą oraz celom regionów (województwa podkarpackiego) w zakresie realizacji priorytetów współpracy międzynarodowej” (ibidem).

W ramach Euroregionalnego Systemu Współpracy wyszczególniono kluczowe obszary aktywności, tzw. akcje tematyczne. Takich akcji tematycznych jest dwanaście, są to: „Młodzież i edukacja”, ,,Turystyka”, „Administracja i rozwój regionalny”, „Sport i rekreacja”, „Społeczeństwo informacyjne”, „Kultura i tradycja”, „Ochrona zdrowia i polityka społeczna”, „Współpraca międzynarodowa i integracja europejska”, „Zarządzanie, gospodarka, handel”, „Nauka i innowacja”, „Ekologia i ochrona środowiska”, „Rozwój obszarów wiejskich” (Stasiak, 2002, s. 238). Euroregionalny System Współpracy jest sposobem na pokonanie przeszkód utrudniających współpracę. Zaczęto odchodzić od myślenia narodowego do myślenia zadaniowego, nakierowanego na większą integrację regionów transgranicznych (Lewkowicz, 2013, s. 36). Zadanie polegające na współpracy ze społecznościami lokalnymi i regionalnymi innych państw to zadanie, które jako takie może stanowić określoną wartość i cel nadrzędny, tylko wówczas, gdy będzie sprzyjać europeizacji i internacjonalizacji życia mieszkańców przy jednoczesnym rozpatrywaniu go z innymi zadaniami publicznymi, których wykonanie dzięki niemu będzie podlegało racjonalizacji i optymalizacji (Kusiak-Winter, 2009, s. 422). Do pierwotnych celów ESW należy zaliczyć wsparcie procesu integracji europejskiej, likwidowanie animozji i sporów przygranicznych, pogłębianie współpracy między narodami Europy, szerzenie identyfikacji europejskiej, wzmocnienie instytucjonalne oraz ograniczenie problemów administracyjnych pojawiających się przy wcześniejszych formach tj. przede wszystkim euroregionach i inicjatywie INTERREG (Grosse, 2012, s. 5-6).

\section{Priorytety Euroregionu Karpackiego od 2018 roku}

6 października 2018 r. w Terchowej na Słowacji odbyło się wydarzenie roczne EC-Day) Programu Interreg V-A Polska-Słowacja 2014-2020 organizowane przez Wspólny Sekretariat Techniczny programu i połączone z obchodami Europejskiego Dnia Współpracy. Uczestnicy zapoznali się z projektami i mikroprojektami dofinansowanymi 
ze środków programu. Była to doskonała okazja do zaprezentowania licznych atrakcji regionu, warsztatów, imprez artystycznych, zabaw dla dzieci, które w istotny sposób sprzyjały integracji mieszkańców po obu stronach granicy. 11 października 2018 r. miało również miejsce Międzynarodowe Karpackie Forum Współpracy - spotkanie różnych przedstawicieli sektora publicznego i prywatnego, reprezentujących poziom krajowy i międzynarodowy. Forum odbyło się pod hasłem „Karpaty - wspólna przestrzeń społeczno-gospodarcza u progu nowych wyzwań”. Forum było miejscem wymiany poglądów, analiz oraz prezentacji kolejnych planów rozwoju regionu karpackiego, takich jak: turystyka karpacka, ochrona środowiska, rozwój lokalny, promocja Euroregionu Karpacki, a zwłaszcza zwrócono uwagę na marketing terytorialny, rolę mediów społecznościowych w promocji obszaru Karpat, a także podsumowano 25 lat istnienia Euroregionu Karpackiego i współpracy transgranicznej. Uhonorowaniem 25-lecia działalności była międzynarodowa Konferencja „Statystyka transgraniczna a spójność przestrzenna - wyzwania i perspektywy". W jej ramach dokonano podsumowania dotychczasowej działalności Euroregionu, efektów współpracy transgranicznej oraz osiągnięć, jakie nastąpiły w rozwoju regionu na przestrzeni tego czasu. Do priorytetów na dalsze lata działalności nadal należeć będzie znaczny rozwój turystyki i obszarów przygranicznych, wymiana doświadczeń, a przede wszystkim, zacieśnianie i umacnianie współpracy oraz integracji między społecznościami lokalnymi, czy regionalnymi, tworzącymi Euroregion Karpacki (Newsletter Stowarzyszenia Euroregion Karpacki Polska).

\section{Podsumowanie}

Funkcjonowanie Euroregionu Karpackiego wywiera ogromny wpływa na rozwój obszarów objętych jego działaniem, a także w widoczny sposób oddziałuje na poprawę warunków życia zamieszkującej go ludności. Wiele działań podejmowanych na tym obszarze było możliwych do zrealizowania, dzięki aktywności Stowarzyszenia działającego na rzecz tego Euroregionu.

Stowarzyszenie Euroregion Karpacki Polska przyczyniło się przede wszystkich do ożywienia różnych dziedzin życia na obszarze współpracy w ramach Euroregionu Karpackiego. Realizacja licznych i bardzo znaczących projektów, mających olbrzymi wpływ na rozwój tego obszaru, doszła do skutku dzięki możliwości zarządzania i wdrażania przez Stowarzyszenie Euroregion Karpacki Polska licznych programów na rzecz rozwoju współpracy transgranicznej. Stowarzyszenie dysponuje środkami unijnymi przeznaczonymi na wdrażanie projektów, zgodnych z ideą rozwoju współpracy transgranicznej w Euroregionie Karpackim. To właśnie możliwość ubiegania się o takie dofinansowanie dla swoich projektów przyciągała wiele organizacji pozarządowych, instytucji publicznych i innych, zachęcając je tym samym do podejmowania licznych inicjatyw, akcji lokalnych i ponadgranicznych, które sprzyjały zwłaszcza ożywieniu gospodarki, edukacji i kultury we wszystkich częściach Euroregionu Karpackiego. Stowarzyszenie Euroregion Karpacki Polska, promując w ten sposób współpracę transgraniczną na tym obszarze, przyczyniło się także do budowy wzajemnego zrozumienia i zaufania pomiędzy ludnością zamieszkującą ten obszar, przezwyciężając tym samym istniejące od wieków urazy i uprzedzenia. 
Reasumując: Euroregion, jako taki „stanowi instytucjonalną formę współpracy transgranicznej i jest obszarem, który geograficznie jest zlokalizowany po obu stronach granicy, gdzie miejscowi mieszkańcy wykazują wolę współpracy" (Furman, 2013, s. 10). Euroregion Karpacki jest wyjątkowy z co najmniej dwóch powodów: - po pierwsze był on prototypem tego typu struktur w skali Europy, po drugie, - składa się z obszarów należących do krajów byłego bloku socjalistycznego. Jego funkcjonowanie wiąże się z licznymi, wymiernymi korzyściami, wśród których można wymienić: zwiększenie inwestycji, napływ kapitału zagranicznego, niwelowanie dysproporcji społeczno-ekonomicznych i generalnie - zwiększenie dynamiki rozwoju gospodarczego, wobec czego, ,można stwierdzić, że nigdy nie było tak dalece posuniętego procesu aktywizacji pogranicza wschodniego, co z pewnością wytycza nowe szlaki współpracy w przyszłości” (Furman).

\section{Bibliografia}

Borys T., Panasewicz Z. (1997), Panorama euroregionów, Urząd Statystyczny, Jelenia Góra.

Borys T. (1999), Obszary transgraniczne w statystyce regionalnej, GUS, Warszawa.

Dobrowolski P., Łata M. (2001), Wielki Region Saar-Lor-Lux: Przykład wspótpracy transgranicznej w Europie, Atla 2, Wrocław.

Ejsmont Z. (1999), Idea euroregionów w warunkach Polski pótnocno-wschodniej, „Studia Regionalne", nr 1.

Europejska Karta Regionów Granicznych i Transgranicznych, https://ocplayer.pl/7365320Europejska-karta-regionow-granicznych-i-transgranicznych-nowelizacja.html.

Europejska Konwencja Ramowa o wspótpracy transgranicznej między wspólnotami $i$ władzami terytorialnymi, Madryt, 21.05.1980 r., Dz. U. 1993, Nr 61, poz. 287, http://msp.money.pl/ akty_prawne/dzienniki_ustaw/.

Furman Ł. (2013), Wspótpraca transgraniczna Polski w ramach Euroregionu Karpaty, Wydawnictwo Stowarzyszenia Współpracy Polska - Wschód, Kielce.

Goliński M. (1999), Gospodarka i informacja, w: W drodze do społeczeństwa informacyjnego, red. J. Lubacz, Warszawa.

Greta M. (2003), Euroregiony a integracja europejska. Wnioski dla Polski, Wydawnictwo Uniwersytetu Łódzkiego, Łódź.

Grosse T. G. (2012), Europejskie Ugrupowanie Wspótpracy Teryrorialnej-ocena dotychczasowych efektów i dalszy rozwój z polskiej perspektywy, „Samorząd Terytorialny”, $\mathrm{nr} 4$.

Gwizdała J. P. (2015), Euroregiony jako forma wspótpracy transgranicznej w Europie, „Zeszyty Naukowe Uniwersytetu Szczecińskiego", nr 855.

Kasperkiewicz W., Mikosik S. (1993), Leksykon przedsiębiorczości, Łódź.

Kusiak-Winter R. (2009), Wspólpraca ze społecznościami lokalnymi i regionalnymi innych państw jako zadanie jednostek samorzadu terytorialnego w Polsce, w: Między tradycją a przyszłościa w nance prawa administracyjnego. Księga Jubileuszowa dedykowana Profesorowi Janowi Bociowi, red. J. Supernat, Wydawnictwo Uniwersytetu Wrocławskiego, Wrocław.

Lewkowicz Ł. (2013), Perspektywy rozwoju euroregionów pogranicza polsko-stowackiego, „Samorząd Terytorialny", nr 12.

Ludność w Euroregionie Karpackim, http://www.stat.gov.pl/cps/rde/xbcr/rzesz/ASSETS_Lud_euro_ pl.pdf.

Malendowski W., Szczepaniak M. (2000), Euroregiony: Mosty do Europy bez granic, Dom Wydawniczy Elipsa, Warszawa. 
Małecka E. (2007), Euroregiony na granicach Polski, GUS, Wrocław.

Newsletter Stowarzyszenia Euroregion Karpacki Polska (2018), nr 4/2018, Rzeszów, http://www. karpacki.pl.

Praktyczny podręcznik wspólpracy transgranicznej, http://www.aebr.net/publikationen/pdfs/lace_ guide.pl.pdf.

Stasiak A. (1999), Problemy rozwoju regionalnego Polski pótnocno-wschodniej i pótnocno-zachodniej, WSE, Białystok.

Stasiak A. (2002), Euroregiony wschodniego pogranicza - założenia i osiagnięcia, WSE, Białystok. Statut Stowarzyszenia Euroregion Karpacki Polska, http://www.karpacki.pl.

Statut Związu Międzyregionalnego „Euroregion Karpacki”, http://www.karpacki.pl/.

Wahl P. (2003), Europejska polityka regionalna, Wyższa Szkoła Integracji Europejskiej, Szczecin.

\section{Streszczenie}

Artykuł przedstawia zagadnienie rozwoju transgranicznego z perspektywy integracji społeczności lokalnych i regionalnych, na przykładzie Euroregionu Karpackiego. W opracowaniu ukazana została współpraca euroregionalna, w której biorą udział społeczności regionalne i lokalne, jako szczególna forma współpracy transgranicznej. Współpraca euroregionalna odbywa się w ramach euroregionu. Podstawą istnienia euroregionów jest wspieranie wymiany gospodarczej i turystycznej, rozwijanie komunikacji, działalność kulturowa oraz wspólne rozwiązywanie problemów transgranicznych.

Słowa kluczowe: współpraca transgraniczna, euroregion, integracja europejska, rozwój regionalny, społeczność lokalna i regionalna

\section{Carpathian Euroregion - an innovative form of integration of local and regional communities in Central and Eastern Europe}

\section{Summary}

The article presents the issue of cross-border development from the perspective of integration of local and regional communities, using the example of the Carpathian Euroregion. The study presents the Euroregional cooperation, in which regional and local communities take part, as a special form of cross-border cooperation. Euroregional cooperation takes place within the Euroregion. The basis of the existence of Euroregions is supporting economic and tourist exchange, developing communication, cultural activities and jointly solving cross-border problems.

Key words: cross-border cooperation, Euroregion, European integration, regional development, local and regional community 